\title{
UPAYA MENINGKATKAN KETERAMPILAN MENULIS SINOPSIS NOVEL “AYAH MENGAPA AKU BERBEDA" KARYA AGNES DAVONAR DENGAN MODEL PEMBELAJARAN STAD OLEH SISWA KELAS XII SMK BM MUHAMMADIYAH 04 MEDAN TAHUN PEMBELAJARAN 2016 - 2017
}

\author{
Abdullah Hasibuan \\ Universitas Muslim Nusantara Al-Washliyah \\ Jl. Garu II No.93 Medan \\ Abdullahhasibuan24@yahoo.com
}

\begin{abstract}
Abstrak
Penulisan sinopsis novel merupakan salah satu sub materi ajar dimuat dalam silabus bahasa indonesia untuk kelas XII SMK BM Muhammadiyah 04 Medan. Proses pembelajaran ini serta hasil penulisan sinopsis selama ini sudah efektif. Teknik yang digunakan untuk meningkatkan keterampilan menulis sinopsis adalah dengan model pembelajaran Stad. Pertama dilakukan adalah pemahaman tentang isi novel tersebut, kemudian siswa disuruh untuk menulis sinopsis. Jika penelitian nanti menunjukkan hasil yang baik antara keterampilan menulis sinopsis novel dengan model pembelajaran stad maka upaya tersebut perlu dipertahankan.Penelitian ini bertujuan untuk memperoleh data objektif tentang Upaya Meningkatkan Keterampilan Menulis Sinopsis Novel "Ayah Mengapa Aku Berbeda"karya Agnes Davonar Dengan Model Pembelajaran Stad Oleh Siswa Kelas XII SMK BM Muhammadiyah 04 Medan Tahun Ajaran 2016-2017. Penelitian ini menggunakan metode deskriptif dengan populasi penelitian adalah seluruh siswa kelas XII SMK BM Muhammadiyah 04 Medan yang terdiri dari empat kelas berjumlah 140 siswa. Sampel penelitian ini adalah sebanyak 35 siswa. Metode penelitian ini adalahPenelitian Tindakan Kelas (PTK) merupakan penelitian yang berbasis kelas, maka masalah-masalah yang diteliti dalam Penelitian Tindakan Kelas (PTK) adalah masalah-masalah yang muncul di kelas. Penelitian Tindakan Kelas (PTK) juga mengupayakan perbaikan kondisi pembelajaran dan menyelesaikan bermacam-macam permasalahan yang muncul di dalamkelas.Teknik analisis data yang digunakan adalah deskriptif kualitatif.
\end{abstract}

Kata Kunci : Sinopsis Novel

\begin{abstract}
Writing a novel synopsis is one of the sub teaching materials applied in syllabus of Bahasa Indonesia for the twelfth grade students of SMK BM Muhammadiyah 04 Medan. This learning process and the result of writing the synopsis so far has been effective. The technique used to improve the skills of writing a synopsis is STAD learning model. The first thing to perform is an understanding of the novel content, and then students are asked to write a synopsis. If the later study shows good results among the skill of writing a novel synopsis with the STAD learning model, then such effort need to be maintained. This research is aimed to obtain the obkective data on the Efforts to Improve Skill in Writing Synopsis of Novel "Ayah Mengapa Aku Berbeda " by Agnes Davonar with Stad Learning Model by the twelfth grade students of SMK BM Muhammadiyah 04 Medan. This research uses descriptive method with the twelfth grade students of SMK BM Muhammadiyah 04 Medan as the population which consists of four classes totaling 140 students. And the sample consists of 35 students. This research method is Class Action Research (CAR) where it is a classroom-based research, so the problems observed in the Classroom Action Research (CAR) is the problems arising in the classroom. Classroom Action Research (CAR) also seeks to improve the learning conditions and resolve various problems arising in the classroom. The technique of data analysis used is descriptive qualitative.
\end{abstract}

Keywords: Novel Synopsis 


\section{PENDAHULUAN}

\subsection{Latar Belakang Masalah}

Keterampilan menulis menjadi suatu keterampilan yang penting untuk dikuasai siswa karena budaya menulis adalah budanya orang terpelajar.Berdasarkan pernyatan tersebut dapat diartikan bahwa membudayakan menulis untuk masyarakat Indonesia adalah dalam rangka meningkatkan mutu dan kualitas sumber daya manusia Indonesia. Proses untuk menuju masyarakat Indonesia yang intelek dan terpelajar dapat diawali dengan penguasaan keterampilan menulis oleh siswa. Menulis bukan sekedar menulis, melainkan sebuah kegiatan yang produktif dan ekspresif. Salah satu kegiatan menulis yang terdapat dalam kurikulum Bahasa Indonesia SMK BM adalah menulis Sinopsis.

\subsection{Tujuan}

Tujuan penulisan ini adalah untuk mengetahui proses dan hasil kemampuan siswa dalam menulis Sinopsis serta memperoleh data objektif tentang Upaya Meningkatkan Keterampilan Menulis Sinopsis Novel "Ayah Mengapa Aku Berbeda"karya Agnes Davonar Dengan Model Pembelajaran Stad Oleh Siswa Kelas XII SMK BM Muhammadiyah 04 Medan Tahun Ajaran 2016-2017 Siswa Kelas XII SMK BM Muhammadiyah 04 Medan Tahun Ajaran 2016-2017.

\subsection{Pendekatan Pemecahan Masalah}

Pendekatan pemecahan masalah penulisan ini adalah menggunakan model pembelajaran STAD oleh siswa kelas XII SMK Muhammadiyah 04 Medan Tahun pembelajaran 2016-2017.

\section{METODE}

Metode yang digunakan dalam penelitian ini adalah penelitian tindakan kelas (Classrom Action Research). Penelitian tindakan kelas merupakan bentuk peneliti praktis yang mengacu kepada apa yang dilakukan peneliti untuk memperbaiki hasil proses kemampuan (Arikunto. 2000:3). Prosedur penelitian tindakan kelas menurut Arikunto
(2006:16) lazimnya mempunyai empat tahapan yaitu:"1,Perencanaan, 2,Pelaksanaan, 3,Pengamatan, dan 4,Refleksi.

Penelitian tindakan kelas dilakukan dalam bentuk siklus, tindakan dalam setiap siklus diawali dengan perencanaan (Planing) melakukan tindakan (Action), mengobservasi dan mengevaluasi ( Observasi and Evaluation), dan melakukan refleksi (Reflection).

\section{Siklus 1}

Siklus pertama dimulai dari perencanaan, kemudian tindakan/pelaksanaan, dilanjutkan dengan pengamatan, dan refleksi, Refleksi siklus pertama akan dijadikan dasar untuk menentukan kebijakanyang akan diambil pada siklus berikutnya.

a. Perencanaan

- Merencanakan Tujuan Pembelajaran

Penelitian ini direncanakan dilaksanakan sampai tervapainya ketuntasan belajar sesuai dengan tuntunan kurikulum yang berlaku. Ukurantercapainyaketuntasan belajar adalah apabila sampel penelitian telahmemenuhi kriteria ketuntasanminimal (KKM) yang ditetapkan sekolah yaitu minimal nilai 65 dengan ketuntasan klasikal sebesar $75 \%$.

- Merencanakan Perangkat Pembelajaran

Pada kegiatan ini disiapkan perangkatperangkat pembelajaran yang mengacu pada unsur-unsur Rencana Pelaksanaan Pembelajaran (RPP) yaitu: (1) Standar kompetensi, (2) kompetensi dasar,(3) indikator, (4) tujuan, (5) meteri pokok, (6) media dan sumber pembelajaran, serta (7) penilaian.

- Merencanakan Metode Pembelajaran Metode pembelajaran yang direncanakan adalah metode penugasan yaitu siswa ditugaskan untuk menulis sinopsis novel yang novelnya sudah disediakan. 
Kemudianmerangcang model pembelajaran, merangcang bentuk dan menyusun model penilaian.

Adapun model penilaian yang ditetapkan adalah sebagai berikut:

a. Menyuruh siswa untuk membaca novel "Ayah Mengapa Aku Berbeda" yang telah disediakan.

b. Penilaian diarahkan pada penulisan sinopsisnya dengan singkat dan tepat.

c. Rentang skor ditetapkan dari 0 s.d 100.

d. Pelaksanaan

Pada tahap ini penulis mengaplikasikan rencana pembelajaran yang telah dirancang sebelumnya.

Cara penerapannya sebagai berikut:

1) Guru menjelaskan tujuan pembelajaran hari itu.

2) Guru menjelaskan apa yang dimaksut dengan sinopsis

3) Guru menjelaskan apa-apa saja langkah untuk menyusun sinopsis

4) Guru merefleksikan pembelajaran hari itu.

5) Guru memeriksa hasil temuansiswa dan memberikan penilaian

6) Guru mengakhiri KBM hari itu.

Pada kegiatan inipenulis sekaligus mengamati jalannya proses belajarmengajar yaitu bagaimana sikap siswa waktu belajar dengan metode yang diterapkan. Tentang sikap siswa ini dibuat pencatatantentang berapa orang yang kelihatan senang, ribut, bingung, bertanya, dan sebaginya.

b. Observasi

Observasi maksudnya adalah kegaitan mengamati proses belajarmengajar sertapengaruh proses belajarmengajar tersebut terhadap siswa. Observasi yang dilakukan berfungsi untuk mengumpulkan data sikap siswa serta dampak tindakan proses pembelajran selama penelitian berlangsung.

c. Refleksi
Kegiatan refleksi ini merupakan pengkajian secara keseluruhanterhadap apa yang telah dilakukan. Untuk memahami proses dan hasil perubahan yang terjadi setelah tindakan dilakukan, danberdasarkandata yang telah terkumpul kemudian dilakukan evaluasi gunamenyempurnakan tindakan berikutnya. Dengan demikian, tindakan dihentikan apabila telah dicapai hasil yang optimal sesuai dengan ketuntasan belajar yang ditentukandalam kurikulum.

2. Siklus 2

Pada siklus ke 2 pelaksanaan tindakan dilakukan sebagaimana prosedur yang diaplikasi pada siklus pertama. Pada siklus ini diusahakan penyempurnaan terhadaphal-hal yang dianggap belumsempurnapada pelaksanaan siklus 1 sesuai dengan hasil refleksi

a. Perencanaan

Setelah diadakan refleksi pada siklus 1, maka disusunpula rencanayang akan dilaksanakan pada siklus ke 2 ini. Perencanaan tersebut didasarkan pada pertimbangan tentang apa yang terjadi, apa yang telah dihasilkan, dan apa yang belum tuntaspada siklus 1 . Perencanaan juga didasarkan pada pertimbangan apakah tindakan yang dilakukanpada siklus 1 telah sesuai dengan prosedur atau belum. Pada perencanaan ini juga diadakan identifikasi masalah dan alternatif pemecahannya.

Sebagaimana halnya dengan siklus 1, pada siklus 2 disiapkan juga perangkat-perangkat pembelajaran yang mengacu pada unsur-unsur Rencana Pelaksanaan Pembelajaran (RPP) yaitu: (1) standar kompetensi, (2) kompetensi dasar, (3) indikator), (4) tujuan, (5) materi pokok, (6) media dan sumber pembelajaran, serta (7) penilaian.

b. Pelaksanaan

Pada siklus ke-2 ini penulis membuka pelajaran sebagaimana pada siklus pertama. Pelaksanaan pembelajaranmenemukan keterampilan 
Abdullah Hasibuan_Upaya Meningkatkan Keterampilan Menulis Sinopsis Novel "Ayah Mengapa AkuBerbeda” Karya Agnes Davonar Dengan Model Pembelajaran STAD Oleh Siswa Kelas XII SMK BM Muhammadiyah 04 Medan Tahun Pembelajaran 2016 - 2017

menulis sinopsis novel dengan model pembelajaran stad lebih disempurnakan dari pelaksanaan pembelajaran siklus 1 . Penyempurnaan dimaksud didasarkandari hasil observasi dan hasil refleksi yang dilaksanakan pada siklus 1. Pada pelaksanaan pembelajaran siklus pertama telah terkumpul data tentang hasil dan sikap siswa ketika prosespembelajaran berlangsung, termasuk keunggulan maupun kelemahan pelaksanan. Kelemahankelemahan yang ditemui pada siklus sebelumnya disempurnakan pada siklus berikutnyasebagai upaya untuk mencapai ketuntasan belajar yang diharapkan.

c. Observasi

Kegiatan observasipada siklus iniakan dilakukan pengumpulan data tindakan pada siklus2. Data tersebut dikumpulkan dengan teknik dan instrumen yang sama dengan siklus 1,sebagai bahan renungan penyempurnaan pada siklusberikutnya.

d. Refleksi

Pada tahap ini diadakan evaluasi tindakan yang telah dilakukan pada siklus 2 serta memperbaiki pelaksanaan tindakan sesuai hasil evaluasi untuk digunakan pada siklus berikutnya apabila ketuntasan belajar yang diharapkan belum tercapai.

\section{HASIL DAN PEMBAHASAN}

3.1. Hasil

1. Data Tes Siklus I

Setelah dilaksanakan Upaya Meningkatkan Keterampilan Menulis Sinopsis Novel"Ayah Mengapa Aku Berbeda"Karya Agnes Davonar Dengan Pembelajaran Model Stad Oleh Siswa Kelas Kelas XII SMK BM Muhammadiyah 04 Medan Tahun Ajaran 2016-2017 Siswa Kelas XII SMK BM Muhammadiyah 04 Medan Tahun Ajaran 2016-2017.

TABEL 3.1

Skor Siklus I Keterampilan Menulis Sinopsis

(Variabel X)

\begin{tabular}{|c|l|c|}
\hline No. & \multicolumn{1}{|c|}{ Nama } & Skor \\
\hline 1 & Abdul Kholid Hamzah & 85 \\
\hline 2 & Ahmad Alwi Hasibuan & 70 \\
\hline 3 & Aisyatul Aslamia Siregar & 70 \\
\hline 4 & Annisa Batubara & 70 \\
\hline 5 & Ayu Derma Rizky Rambe & 65 \\
\hline 6 & Cindi Setia Ningsih & 65 \\
\hline 7 & Dea Gumala & 55 \\
\hline 8 & Elisa Febriyanti Siregar & 65 \\
\hline 9 & Fadhilah Hayati Harahap & 65 \\
\hline 10 & Fadilah Shandi Lubis & 75 \\
\hline 11 & Dahrul Rozi & 65 \\
\hline 12 & Fitirani Siregar & 55 \\
\hline 13 & Habibah Salma Putri & 65 \\
\hline 14 & Hafifah Ulfa Ritonga & 65 \\
\hline 15 & Hafifih Wildayani & 60 \\
\hline 16 & Helmi Hakimah & 60 \\
\hline 17 & Isra Ainun Hasibuan & 70 \\
\hline 18 & Jenifah Zahara & 55 \\
\hline 19 & Latifah Hannum & 60 \\
\hline 20 & Marhammi Ritonga & 65 \\
\hline 21 & Muhammad Fahrul Rozi & 60 \\
\hline 22 & Mutiah Gurdani Siregar & 65 \\
\hline
\end{tabular}



AkuBerbeda" Karya Agnes Davonar Dengan Model Pembelajaran STAD Oleh Siswa Kelas XII SMK BM Muhammadiyah 04 Medan Tahun Pembelajaran 2016 - 2017

\begin{tabular}{|l|l|c|}
\hline 23 & Novidah Riyanti & 65 \\
\hline 24 & Nur Saidah & 60 \\
\hline 25 & Nurazizah Matondang & 65 \\
\hline 26 & Nurul Aulia & 70 \\
\hline 27 & Nurul Khasanah & 65 \\
\hline 28 & Olivia Andrini & 60 \\
\hline 29 & Rahmad Hasibuan & 70 \\
\hline 30 & Rafifah Hasibuan & 75 \\
\hline 31 & Rika Anggita & 70 \\
\hline 32 & Sindi Melani Hasibuan & 80 \\
\hline 33 & Sofyan Sauri & 80 \\
\hline 34 & Sahrul Hidayat Nasution & 70 \\
\hline 35 & Sri Mahrani Syafa & 80 \\
& Harahap & 2270 \\
\hline \multicolumn{2}{|c|}{ Jumlah } & 66,85 \\
\hline
\end{tabular}

Berdasarkan deskripsi data tes siklus I diatas diketahui bahwa rata-rata skor para siswa sebesar 2270:35=66,85. Apabila rata-rata skor tersebut dikonvensikan dengan kualifikasi kemampuan yang dikemukakan diatas berarti keterampilan siswa menulis sinopsis novel termasuk kategori cukup karena antara $61-70 \%$ atau 70 yang penafsirannya sama dengan kriteria kemampuan cukup.

2. Data Tes Siklus II

Sebelum proses pembelajaran Upaya Meningkatkan Keterampilan Menulis Sinopsis Novel"Ayah Mengapa Aku Berbeda"Karya Agnes Davonar Dengan Model Pembelajaran Stad dilaksanakan pada siklus II terlebih dahulu disiapkan rencana pembelajaran yang lebih sempurnah dari siklus pertama. Penyempurnaan dimaksud antara lainmemperbanyak contoh meningkatkan keterampilan menulis sinopsis dengan pembelajaran model stad. Setiap siswa disuruh membuat contoh dipapan tulis. Kemudian menasehati para siswa yang berperilaku negatif selama prosespembelajaran berlangsung agar suasana pembejaran dirasakan lebih kondusif dari pada siklus I.

Setelah dilaksanakan perbaikan pembelajaran meningkatkan keterampilan menulis sinopsis pada siswa diperoleh data sebagaimana pada tabel berikut.

TABEL 3.2

Skor Siklus II Keterampilan Menulis Sinopsis Siswa

(Variabel Y)

\begin{tabular}{|c|l|c|}
\hline No. & Nama & Skor \\
\hline 1 & Abdul Kholid Hamzah & 75 \\
\hline 2 & Ahmad Alwi Hasibuan & 70 \\
\hline 3 & Aisyatul Aslamia Siregar & 80 \\
\hline 4 & Annisa Batubara & 75 \\
\hline 5 & Ayu Derma Rizky Rambe & 80 \\
\hline 6 & Cindi Setia Ningsih & 80 \\
\hline 7 & Dea Gumala & 70 \\
\hline 8 & Elisa Febriyanti Siregar & 75 \\
\hline 9 & Fadhilah Hayati Harahap & 75 \\
\hline 10 & Fadilah Sandy Lubis & 70 \\
\hline 11 & Dahrul Rozi & 70 \\
\hline 12 & Fitirani Siregar & 80 \\
\hline 13 & Habibah Salma Putri & 80 \\
\hline
\end{tabular}




\begin{tabular}{|c|l|c|}
\hline 14 & Hafifah Ulfa Ritonga & 75 \\
\hline 15 & Hafifih Wildayani & 75 \\
\hline 16 & Helmi Hakimah & 80 \\
\hline 17 & Isra Ainun Hasibuan & 85 \\
\hline 18 & Jenifah Zahara & 80 \\
\hline 19 & Latifah Hannum & 85 \\
\hline 20 & Marhammi Ritonga & 85 \\
\hline 21 & Muhammad Fahrul Rozi & 70 \\
\hline 22 & Mutiah Gurdani Siregar & 75 \\
\hline 23 & Novidah Riyanti & 80 \\
\hline 24 & Nur Saidah & 80 \\
\hline 25 & Nurazizah Matondang & 70 \\
\hline 26 & Nurul Aulia & 75 \\
\hline 27 & Nurul Khasanah & 70 \\
\hline 28 & Olivia Andrini & 75 \\
\hline 29 & Rahmad Hasibuan & 70 \\
\hline 30 & Rafifah Hasibuan & 70 \\
\hline 31 & Rika Anggita & 75 \\
\hline 32 & Sindi Melani Hasibuan & 80 \\
\hline 33 & Sofyan Sauri & 85 \\
\hline 34 & Sahrul Hidayat Nasution & 70 \\
\hline 35 & Sri Mahrani Syafa & 80 \\
& Harahap & 2670 \\
\hline & Jumlah & 76,28 \\
\hline & Rata-rata & \\
\hline
\end{tabular}

Kalau diperhatikan data siklus II di atas diketahui bahwa rata-rata skor para siswa mencapai 2670:35=76,28. Apabila rata-rata skor tersebut dikonversikan dengan kualifikasi kemampuan yang dikemukakan di atas berarti keterampilan menulis sinopsis siswa termasuk kategori baik karenaratarata skor 73.28 di atas berada diantara tingkat penguasaan antara $71-80 \%$ atau skor 80 yang penapsiraanya $=$ kriteria kemampuan baik.

\subsection{Pembahasan}

Keterampilan menulis sinopsis siwa ternyata meningkat setelah menggunakan model pembelajaran stad pada siklus pertama menjadi kategori cukup dengan rata-rata skor 65 . Skor para siswa cukup bervariasi dengan skor terendah sebesar 55 sedangkan tertinggi 85. Ketuntasan belajar telah mencapai $68,97 \%$ atau 20 dari 35 siswa. Ketuntasan belajar tersebut belum memenuhi tuntutan kurikulum yang berlaku yaitu minimal tuntas $75 \%$ secara klasikal. Akan tetapi sikap yang teramati selama proses pembelajaran siklus pertama berlangsung, ditemukan 5 siswa atau $17,24 \%$ yang suka mengganggu temannya ketika belajar, dan 6 siswa atau 20,69\% yang tidak mengerjakan tugas. Berdasarkan hal tersebut penulis memutuskan untuk melanjutkan perbaikan pada siklus berikutnya.

Keterampilan menulis sinopsis pada siklus II meningkat lagi menjadi kategori kemampuan baik dengan ratarata skor 73,28 . Skor para siswa cukup bervariasi dengan skor terendah sebesar 55 sedangkan tertinggi 100. Sedangkan ketuntasan belajar telah mencapai $100 \%$. Pada siklus II terjadi perubahan sikap menjadi lebih positif terhadap model pembelajaran stad. Berdasarkan pengamatan selama proses pembelajaran siklus kedua berlangsung, sikap negatif siswa telah berkurang yaitu sebelumnya ditemukan siswa atau $17,24 \%$ yang ribut 
dikelas, pada siklus ini hanya 1 siswa atau 3,45 \% saja. Pada siklus pertama ditemukan 3 siswa atau 10,34 \% yang permisi keluar kelas, sedangkan padasiklusyang kedua tidak ada lagi. Siswa yang tidak aktif belajar pada siklus pada pertama ada 4 siswa atau 13,79\%, sedangkan pada siklus kedua hana 2 siswa atau $6,9 \%$ saja. Siswa yang suka mengganggu temannya ketika belajarpada siklus pertama sebanyak 5 siswa atau 17,24\%, pada siklus kedua berkurang menjadi hanya 1 siswa atau $3,45 \%$ saja, dan pada siklus pertama ditemukan 6 siswa atau 20,69\% yang tidak mengerjakantugas sedangkanpada siklus kedua hanya 2 siswa atau $6,9 \%$ saja..

Berdasarkan data tes di atas diketahui bahwa telah terjadi proses meningkatnya keterampilan menulissinopsis dengan model pembelajaran stad sebagai berikut: pada pratindakan atausebelum menggunakan model pembelajaran stad untuk meningkatkan keterampilan menulis sinopsis, hanya 7 siswa atau $24,14 \%$ yang termasuk kriteria cukup sedangkan 22 siswa atau $75,86 \%$ ternyata termasuk kriteria kurang. Sedangkan yang termasuk kriteria baik, baik sekali apalagi kriteria sempurna tidak ada. Pada siklus pertama terjadi meningkatnya keterampilan menulis sinopsis yaitu ditemukan 1 siswa atau $3,45 \%$ termasuk kriteria baik sekali, 1 siswa atau 3,45\% kriteria baik, 18 siswa atau $62,07 \%$ kriteria cukup dan tinggal 9 siswa atau31,03\% saja yang kemampuannya termasuk kriteria kurang, sedangkan kriteria baik sekali dan sempurna belum ada.

Pada siklus kedua setelah dilaksanakan perbaikan pembelajaran khususnya pada para siswa yang belum tuntas serta ribut di kelas, mengganggu teman,meminta izin keluar kelas dan yang malas mengerjakan tugas ketika proses pembelajaranberlangsung terjadi meningkatnya pada hasil belajar dan sikap siswa. Pada siklus kedua ditemukan 3 siswa atau 10,34\% yang berhasil memproleh kriteria kemampuan sempurna, 2 siswa atau 6,9\% termasuk kriteriabaik sekali, 9 siswa atau 31,03\% termasuk kkriteria kurang.

\section{KESIMPULAN.}

Berdasarkan penelitian yang telah dilakukan menunjukkan bahwa skor perolehan tentang upaya meningkatkan keterampilan menulis sinopsis menyebar dari skor rendah 55 sampai skor tertinggi 85. dimana hasil perhitungan diketahui nilai rata-rata dari keterampilan menulis sinopsis pratindakan diperoleh nilai ratarata adalah56,85 jadi, keterampilan menulis sinopsis siswa kelas Kelas XII SMK BM Muhammadiyah 04 Medan berada pada kategori kurang. Hasil penelitian keterampilan menulis sinopsis pada pratindakan dengan memperoleh nilai rata-rata 56,85 masih termasuk kurang. Jadi penelitian akan melanjutkan pada siklus I. Setelah diadakan pembelajaran pada siklus I tentang upaya meningkatkan keterampilan menulis sinopsis pada siklus I,maka diperoleh nilai rata-rata adalah 66,85. jadi, keterampilan menulis sinopsis siswa kelas Kelas XII SMK BM Muhammadiyah 04 Medan Tahun Ajaran 2016-2017 Siswa Kelas XII SMK BM Muhammadiyah 04 Medan berada pada kategori cukup.Kemudian, keterampilan menulis sinopsis pada siklus I masih kategori cukup peneliti akan melanjutkanpada siklus ke II. Pada siklus ke II ini nilai rata-rata yang diperoleh adalah 76,28 jadi, keterampilan menulis sinopsis siswa kelas Kelas XII SMK BM Muhammadiyah 04 Medan Tahun Ajaran 2016-2017 berada pada kategori baik, karena peneliti sudah memperoleh hasil yang baik maka peneliti tidak perlu lagi melanjutkan pada siklus berikutnya.

\section{DAFTAR PUSTAKA}

Abd. Syukur Ibrahim Dwi Saksomo. $1987 . \quad$ KesustraanIndonesia. Surabaya : Usaha Nasional. 
Arikunto Suharsimi.2010.

ProsedurPenelitian : Suatu

Pendekatan Praktik. Jakarta : Rineka Cipta

Enda Tri Priyatni. 2012

MembacaSastraDenganAncangan

LiterasiKritis. Jakarta : Bumi Aksara

Simatupang, Iwan. Koong. Jakarta: Pustaka Jaya, 1975.

Sumardjo, Jakop. Sinopsis Roman.

Bandung: Alumni, 1983.

Tarigan, Henri Guntur. 2005. Menulis Sebagai Suatu Keterampilan Berbahasa. Bandung : Angkasa

Tarigan, Henri Guntur.1984. PrinsipPrinsipDasarSastra. Bandung: Angkasa. 